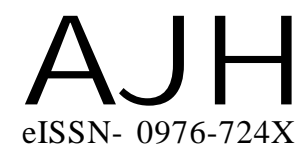

Received : 22.01.2016

Revised : 14.04 .2016

Accepted : 26.04.2016

Members of the Research Forum

Associated Authors:

${ }^{1}$ Department of Fruits Crops, Tamil

Nadu Agricultural University,

COIMBATORE (T.N.) INDIA
Author for correspondence :

K. VANILARASU

Department of Fruits Crops, Tamil

Nadu Agricultural University,

COIMBATORE (T.N.) INDIA

Email : arasuvani88@gmail.com
THEASIAN JOURNAL OF HORTICULTURE

Volume 11 | Issue 1 | June, 2016 | 63-67

Visit us -www.researchjournal.co.in

\title{
Impact of alternative energy sources on growth and yield of banana cv. GRAND NAINE
}

\section{K. VANILARASU, G. BALAKRISHNAMURTHY ${ }^{1}$ AND K. SOORIANATHASUNDARAM ${ }^{1}$}

ABSTRACT : Of late growing awareness on health and environmental issues associated with the intensive use of chemical inputs has led to interest in alternate forms of agriculture in India as well as in the world. An investigation was carried out during 2010-2011, to study the effect of organic manures, organic amendments and green manures in comparison with inorganic fertilizers on growth, development, yield and yield of banana cv. GRAND NAINE. The treatment $\mathrm{T}_{10}$ with the combined application of organic manures, amendments and green manures (Farmyard manure @ $10 \mathrm{~kg}$ + Neem cake @ $1.25 \mathrm{~kg}$ + Vermicompost @ $5 \mathrm{~kg}$ and Wood ash @ $1.75 \mathrm{~kg} / \mathrm{plant}+$ triple green manuring with sunhemp + Double intercropping of Cowpea + biofertilizers viz., Vesicular Arbuscular Mycorrhizae @ $25 \mathrm{~g}$, Azospirillum @ 50 g, Phosphate Solubilizing Bacteria @ $50 \mathrm{~g}$ and Trichoderma harzianum @ 50 g/plant) registered the maximum growth (Pseudostem height and girth -218 and $69.53 \mathrm{~cm}$, number of leaves -14.56 and leaf area index -3.79 ) and yield (bunch weight $-27.96 \mathrm{~kg}$, finger length and girth -23.56 and $15.12 \mathrm{~cm}$, finger weight $-280.25 \mathrm{~g}$, pulp and peel weight -194.13 and $65.27 \mathrm{~g}$ ) characters under drip irrigation.

KEY WORDS : Organic manures, Amendments, Growth, Yield

HOW TO CITE THIS ARTICLE : Vanilarasu, K., Balakrishnamurthy, G. and Soorianathasundaram , K. (2016). Impact of alternative energy sources on growth and yield of banana cv. GRAND NAINE. Asian J. Hort., 11(1) : 63-67, DOI : 10.15740/HAS/TAJH/11.1/63-67. 